Karolina Mazurowska

(Szkoła Wyższa Psychologii Społecznej w Warszawie)

\title{
Kulturowe uwarunkowania zachowań współczesnych Chińczyków. O godności, szacunku, honorze, czyli zasadzie zachowania twarzy
}

W kulturze chińskiej poczucie dumy, zadowolenie z siebie, ale także zażenowanie, wstyd czy upokorzenie wywodzą się bezpośrednio z koncepcji „,posiadania” lub „utraty” twarzy. „Posiadanie” lub „utrata” twarzy jest szczególnie problematyczne $\mathrm{w}$ niepewnych sytuacjach społecznych, takich jak: prośba, zażenowanie, konflikt, gdy tożsamość zaangażowanych osób jest poddana próbie ${ }^{1}$. Ludzie w różnych kulturach próbują „zachować twarz”, negocjować pewne przywileje dla siebie za pomocą wizerunku. Jednakże obawa przed utratą twarzy jest większą stygmatyzacją w kulturach o ścisłej strukturze społecznej i sztywnej hierarchii, takiej jak kultura chińska.

Koncepcja „twarzy” jest nierozerwalnie związana z kształtowaniem obrazu jednostki, rozwojem relacji interpersonalnych pomiędzy Chińczykami, strategiami $\mathrm{w}$ komunikacji i dyskusji, jakie preferują Chińczycy w danej sytuacji społecznej.

\section{Mianzi oraz lian - różnice koncepcji}

Według naukowców, którzy zajmowali się dystynkcją pojęcia „twarz” mianzi odnosi się bardziej do „,wizerunku”; do tego rodzaju prestiżu, jaki doceniany jest w szeroko pojętej kulturze zachodniej. Niektórzy badacze ${ }^{2}$ ujmują to $\mathrm{w}$ kategoriach reputacji, na jaką pracuje jednostka przez całe swoje życie a także w kategoriach sukcesu. Natomiast $\mathrm{Cheng}^{3}$ odnosi mianzi do odpowied-

${ }^{1}$ S. T in g-T o o mey, (1988). Intercultural conflict styles: a face negotiating theory, [w:] ed. Y. Y. Kim, W. B. Gudykunst, Theories in Intercultural Communication. Sage Publications, Newbury Park, s. 213-255.

${ }^{2}$ M. H. B o n d, Beyond of the Chinese face, Oxford University Press, Hong Kong, 1991.

${ }^{3}$ S. Y. C h e n g, The Concept of Face and its Confucian Roots, ,Journal of Chinese Philosophy" 1986, No. 13, s. 333. 
niego zachowania jednostki zgodnie $\mathrm{z}$ piastowanym urzędem. Im wyższe stanowisko, tym większa i silniejsza mianzi a przez to większe szanse na uzyskanie upragnionego celu. Źródłem mianzi są często także relacje społeczne, takie jak między rodzicem a dzieckiem, nauczycielem a uczniem lub szefem a podwładnym. Mianzi odgrywa przez to rolę podtrzymywania tych kontaktów, rozszerzania ich czy też degradowania wraz z wzajemnym szacunkiem osób w niego zaangażowanych. „Danie” komuś mianzi jest wyrazem szacunku, docenienia jego osiągnięć oraz wdzięczności. Utrata mianzi wiąże się z deprecjacją czyjegoś statusu społecznego, utratą stanowiska, itd.

Pojęcie lian reprezentuje przekonanie społeczeństwa o integralności moralnego charakteru ego każdej jednostki, którego utrata (rozbicie) powoduje niemożność dalszego działania wewnątrz danej grupy ${ }^{4}$. Wyznacza godność, honor oraz szacunek, jakim cieszy się jednostka. Lian oznacza zarówno społeczną sankcję regulującą standardy moralne $\mathrm{w}$ danym środowisku jak i sankcję wewnętrzną, za pomocą której jednostka sama reguluje swoje zachowanie a za utratę lian może obwiniać tylko siebie. Lian jest maską ochronną, którą zakłada dana osoba, gdy komunikuje się z innymi. Gdy ją straci, zostaje uznana za człowieka poniżej godności moralnej. Lian stanowi minimum społecznego szacunku przypisanego jednostce obojętnie od jej aktualnej pozycji społecznej, prestiżu, bogactwa czy siły oddziaływania (wpływów) ${ }^{5}$.

\section{Różnice w rozumieniu pojęcia ,twarz” w kulturze chińskiej i zachodniej}

Koncepcja twarzy nie ma jedynie chińskich implikacji - istnieje globalnie, aczkolwiek jej mentalny profil różni się w zależności od standardów danej kultury. W pracach zachodnich naukowców opiera się na teorii autoprezentacji ${ }^{6}$ oraz teorii samookreślania i zachowywania się w zależności od miejsca i sytuacji ${ }^{7}$. Tego rodzaju czynności mają na celu uzyskanie respektu osób, z którymi w danej chwili jednostka jest w kontakcie.

W kulturach indywidualistycznych, w których struktura społeczna jest dosyć rozluźniona, istotnym elementem dla określenia jednostki w kontekście społecznym jest jej indywidualne poczucie wartości, własny pozytywny wizerunek oraz odpowiednia autoprezentacja. Większą wagę przywiązuje się w tych kulturach do jednostki, niż do społeczności, co jest wynikiem zwiększonej

${ }^{4}$ M. H. B o n d, K. K. H u a ng, The social psychology of Chinese people, [w:] The psychology of the Chinese people, ed. M. H. Bond, Oxford University Press, Oxford 1986, s. 243.

${ }^{5}$ S. Y. C h e n g, op. cit., s. 336.

${ }^{6}$ E. G of $\mathrm{f} \mathrm{m}$ a n, On face work: An analysis of ritual elements in social interaction, ,Journal of the Study of the International Processes" 1955, No. 18, s. 213-231.

${ }^{7}$ M. H. B o n d, K. K. H u a ng, The social psychology..., s. 245. 
mobilności, przemieszczania się grup, a także rozpadu tradycyjnej rodziny (składającej się z dzieci, rodziców, dziadków, kuzynów itd.). Społeczeństwa zachodnie są w tej chwili w znacznej mierze egalitarne, co oznacza, że wszyscy ich członkowie są równi, a utrata „twarzy” nie powoduje dezintegracji grupy, która nie stanowi już istotnego punktu odniesienia dla jednostki. Ważna jest integralność i spójność , ja” jednostkowego.

W kulturze chińskiej natomiast „twarz” jest związana z tym, co inni ludzie myślą o danym Chińczyku, jakie wartości w nim zauważaja, jak ,inni” go przedstawiają, szczególnie w odniesieniu do grupy społecznej, do której dany Chińczyk przynależy. Nadrzędną wartością jest społeczne uznanie i pozytywny wizerunek w kręgu osób, do których członek kultury chińskiej odnosi się w codziennym życiu.

Żeby zrozumieć, jak duże znaczenie ma pojęcie „twarz” w kulturze chińskiej, należy uwzględnić jej inne istotne cechy - hierarchiczną strukturę społeczeństwa oraz trwałość statusu, jaki ma dana jednostka. W społeczeństwie zachodnim każdy ma jednakowo wolny wybór co do form zachowania, komunikacji i wypowiadania się. Ambicja oraz możliwości jednostki wyznaczają granice jej postępowania. Gdy jednostka posiądzie umiejętność gry „twarzą”, wtedy może jej używać niezależnie od innych. Na drugim biegunie znajdują się Chińczycy, z których każdy ma inne warunki do „grania twarzą”, bowiem zachowanie to wyznaczane jest przez ich społeczną pozycję oraz jej symbole.

Mając na uwadze fakt, że prezentowanie własnego wizerunku pozostawia trwałe wrażenie, Chińczycy wykazują szczególną ostrożność w postępowaniu. Praca za pomocą wizerunku/twarzy (face work) jest dla członków kultury chińskiej rodzajem przedstawienia (frontstage behavior), które jednostka odgrywa przed innymi. W kulturze chińskiej możemy wyróżnić różnego typu zachowania, odnoszące się do koncepcji twarzy, w zależności od celu, na jaki są nastawione. Może to być działanie, którego efektem będzie poprawienie własnego wizerunku w oczach innych poprzez te czynności, które są dobrze przez nich widziane. Mając na uwadze poprawienie czyjegoś wizerunku, dana osoba może używać strategii przypochlebiania się. Zwykle odgrywa ową rolę ten, kto ma niski status, przez to mniejszą moc oddziaływania na innych, dlatego też działa na rzecz wzmocnienia wizerunku osoby stojącej w hierarchii nad nim. Efektem może być odwdzięczenie się i próba poprawy jego prestiżu na oczach innych, a więc doprowadzenie do sytuacji, gdy wszystkie strony interakcji mają twarze.

\section{Sposoby „ocalenia” lub „odbudowania twarzy” w kulturze chińskiej}

Gdy osoba straci twarz przed innymi, wtedy jej zachowanie, niezgodne $\mathrm{z}$ normami moralnymi obowiązującymi $\mathrm{w}$ danym społeczeństwie (a w chińskim mają one szczególne znaczenie, wyznaczając status), ma poważne konsekwen- 
cje. Gdy jednostka gwałci społeczne zasady moralne w celu osiagnięcia korzyści, może zostać uznana za taką, która „nie chce posiadać twarzy” (bu yao lian) albo „nie ma twarzy” (mei you lian). Oznacza to dla niej brak możliwości dalszego działania, ponieważ straciła do tego „mandat moralny”. W konsekwencji jej zachowanie kładzie cień na całą rodzinę.

Inaczej wygląda sytuacja, gdy jednostka straciła „twarz” i w rezultacie odczuwa zawstydzenie, zażenowanie czy też nieśmiałość. Wtedy jej czynności nastawione są na uratowanie/odbudowanie wizerunku w ramach:

a) kompensacji (poprzez reinterpretację sytuacji jako takiej, w której nie działała swobodnie i wyjaśnieniem jej innym, prośbą o wybaczenie podparta widoczną pracą nad poprawieniem swoich błędów). W ekstremalnych przypadkach głębokiego poniżenia jednostka może nawet popełnić samobójstwo;

b) odwetu, gdy za utratę twarzy obwinia się inne osoby. Skoro jednak otwarte wyrażanie gniewu i niezadowolenia jest niedopuszczalne w chińskim społeczeństwie, wtedy Chińczyk musi grać subtelnie i niebezpośrednio, czekając na odpowiedni moment dla rewanżu;

c) reakcji obronnych poprzez deprecjonowanie oponenta, który doprowadził do zagrożenia wizerunku danej osoby, obniżanie powagi sytuacji, kiedy to nastąpiło, udawanie, że nic się nie stało itd.

\section{Praktyczne implikacje wynikające z koncepcji ,twarzy”}

Chińczycy bardzo troszczą się w codziennym życiu o zachowanie twarzy u drugiej osoby, z którą są w relacji. Przedstawia to poniższa konwersacja:

A: Czy wybierasz się na to przedstawienie w sobotę?

B: Obawiam się, że nie pójdę. Zostałam zaproszona na koncert fortepianowy.

A: Myślałem, że nie lubisz tego rodzaju muzyki?

B: To prawda, ale mam poczucie, że muszę się tam pokazać, żeby dać mojemu znajomemu ,twarz"8.

Powyższy dialog pokazuje, jak Chińczycy widzą swoje stosunki ze znajomymi (ważne jest podtrzymanie relacji, niedopuszczenie do odmówienia zaproszeniu a więc ochrona twarzy), a także jak widzą siebie w swojej grupie społecznej (nawet, gdy nie lubią danej muzyki, nie patrzą na swoje preferencje tylko na zaproszenie drugiej osoby; kładą nacisk na relacje z osobą, na której im zależy).

Chińczycy często wykorzystują mianzi jako swój społeczny kapitał do proszenia innych osób o różne przysługi. Gdy twarz danej osoby jest poddana próbie $\mathrm{w}$ sytuacji prośby, istnieje małe prawdopodobieństwo, że spotka się z od-

${ }^{8}$ G. Ga o, S. Ting-T o o mey, Communicating Effectively with the Chinese, rozdz. 4: Mianzi, Sage Publications, London 1998, s. 53-68. 
mową, co przedstawia następujący przykład: „Xiao Geng pomógł mi bardzo w przeciagu ostatnich dwóch lat. Czy mógłbyś dać mi mianzi wyświadczając mu przysługę?" "Zaangażowanie własnej mianzi w tej relacji jest oczywiste.

Natura relacji pomiędzy Chińczykami jest istotnym wyznacznikiem tego, czy „dać” lub „kontestować” czyjąś mianzi. Oczywiście trudniej jest podważać twarz osoby znajomej, o czym świadczy następujący przykład:

Ostatnio sekretarka przedstawiła w moim departamencie swojego młodszego brata. Nie jest on jednak typem podwładnego, którego poszukuję, ale wezmę go jednak „na próbę” - tylko, dlatego, żeby dać mianzi jego siostrze ${ }^{10}$.

Chiang $^{11}$ uważa, że w chińskiej tradycji „twarz” obu osób wchodzących w relację jest ważniejsza, niż wiarygodność. Żeby ochronić twarz, Chińczycy są gotowi w czasie dyskusji powiedzieć „tak”, nawet, gdy się z czymś nie zgadzają. Jak argumentują Bond i Lee ${ }^{12}$, ochrona czyjejś twarzy jest ważniejsza, niż poczucie prawdy i prawości. Jest to motywowane potrzebą ochrony własnego wizerunku i chęcią niedopuszczenia do bycia źle osądzonym przez innych. Tego rodzaju zachowania zostały uznane za ,syndrom mianzi”.

Wpływ mianzi może być zauważony w wielu aspektach życia w Chinach. Podczas badania biznesmenów średniego szczebla w Hongkongu Redding i $\mathrm{Ng}^{13}$ zauważyli, że istnieje wiara $\mathrm{w}$ zależność pomiędzy osiaganiem sukcesu w transakcjach biznesowych i negocjacjach a posiadaniem „twarzy” i ,dawaniem twarzy” partnerom biznesowym. „Danie komuś twarzy” w czasie negocjacji jest wielce pożądane, a wystawianie twarzy na próbę (np. poprzez kwestionowanie wartości i umiejętności partnera) uznawane za szkodliwe dla relacji. Uczucia takie jak satysfakcja, duma, wzmocniona pewność siebie wiążą się z uzyskaniem twarzy, natomiast negatywne emocje, jak wstyd, obawa, strach, napięcie w negocjacjach - za utratę twarzy ${ }^{14}$.

Uwaga, którą przypisuje się twarzy w kulturze chińskiej reguluje treści, jakie można wyjawiać w relacjach interpersonalnych. Sztywne zasady „odsłaniania siebie” (self-disclosure) można wyczytać z powiedzeń takich, jak: „Jia chou bu ke wai yang" ${ }^{\text {"15 }}$. Złe zachowanie czy pogwałcanie pewnych reguł rzadko

${ }^{9} \mathrm{G} . \mathrm{G}$ a o, An initial analysis of the effects of face and concern for ,other” in Chinese interpersonal communication, „International Journal of Intercultural Relations” [w druku].

${ }^{10}$ G. G a o, S. T i n g - T o o m e y, Communicating Effectively..., s. 58.

${ }^{11}$ O. C h i a n g, On face and credibility „Chinese American Forum”, 1989, No. 5(1), s. 14.

${ }^{12} \mathrm{M}$. H. B o n d, P. L e e, Face saving in Chinese culture: A discussion and experimental study among Hong Kong students, [w:] Social life and development in Hong Kong, ed. A. Y. C. King, R. P. L. Lee, Chinese University Press, Hong Kong 1981.

${ }^{13} \mathrm{G}$. S. R e d d in g, M. N g, The role of the face in the organizational perceptions of Chinese managers, „Organizational Studies” 1982, No. 3, s. 201-219.

${ }^{14}$ G. G a o, S. T i n g - T o o m e y, Communicating Effectively..., s. 58.

15 „Niepowodzenia rodzinne nie powinny być wyjaśniane na zewnątrz”. Ibidem, s. 59. 
wydostaje się poza dyskusje w rodzinie, dlatego też nie słyszy się wśród Chińczyków większych dyskusji na temat dysfunkcji rodzinnych, złych relacji pomiędzy małżonkami czy otyłości wśród dzieci u zaprzyjaźnionych rodzin. Publiczne upokorzenie dziecka np. poprzez danie mu klapsa czy publiczna kłótnia małżonków może spowodować utratę twarzy nie tylko ich, ale także całej rodziny. Chińscy rodzice uczą dzieci właściwych zachowań mówiąc: „Bie diu zan jia de lian"16.

\section{Wpływ „twarzy” na strategie komunikacyjne Chińczyków}

Uwaga, z jaką traktuje się twarz partnera wpływa na wybór strategii komunikacyjnych. Jako że w chińskim społeczeństwie porządek ustanawiany przez hierarchię jest niezwykle istotny, jednostka musi zważać na nieskazitelny wizerunek innych, a w szczególności swoich przełożonych. Chińczycy wykazuja zwykle wielką niechęć do popadania w konflikt, konfrontacji i krytyki pod adresem innych. W chińskiej kulturze jednostka za wszelką cenę będzie starała się unikać konfliktu, ponieważ stanowi on zagrożenie dla twarzy jej i partnera w dyskusji. Bezpośrednia konfrontacja kojarzy się Chińczykom z luan chaosem, który przeszkadza w układaniu harmonijnych relacji z innymi. Dlatego należy troszczyć się o opinię innych i antycypować ich reakcje na swoje zachowanie. Istotne jest używanie nieofensywnej strategii $\mathrm{w}$ celu osiągnięcia upragnionego celu, a także unikanie kary, odrzucenia, śmieszności, zażenowania ${ }^{17}$, które mogą wystapić w czasie konfliktu czy konfrontacji.

Chińczycy doceniają, gdy do sytuacji konfliktowych podchodzi się z dużą dawką samokontroli i wykorzystuje umiejętność powstrzymywania wszelkich emocji. W ramach pewnego badania Chińczycy zostali zapytani o to, co zrobiliby, gdyby mieli sprzeczkę z sąsiadem i zostali słownie obrażeni. Więcej niż połowa respondentów odpowiedziała, że powstrzymaliby się od werbalnej reakcji, a jedna trzecia z nich udałaby się do wspólnoty sąsiedzkiej z prośbą o rozstrzygnięcie sporu ${ }^{18}$. Gdyby doszło do podobnej sytuacji - wymiany sprzecznych opinii - w pracy, więcej niż połowa badanych Chińczyków „nic by nie powiedziała”, „poprosiła lidera grupy (szefa) o mediacje”, „poprosiła osobe trzecią" o bezpośrednie zaangażowanie $\mathrm{w}$ konflikt ${ }^{19}$. Tak więc większość Chińczyków obrałaby strategię unikania konfrontacji lub pośredniego rozwiązania sporu przy pomocy innych osób, gdyby do niego doszło. „Nawet w najbar-

16 „Nie spowoduj utraty twarzy naszej rodziny”. Ibidem, s. 60.

${ }^{17}$ K. S. Y a n g, Social orientation and individual modernity among Chinese students in Taiwan, ,Journal of Social Psychology” 1981, No. 113, s. 159-170.

${ }^{18}$ G. G a o, S. T i n g - T o o m e y, Communicating Effectively..., s. 61.

${ }^{19}$ Ibidem, s. 61. 
dziej konfrontacyjnych sytuacjach chińską normą społeczną nie jest doprowadzenie do ostatecznego zrujnowania publicznego wizerunku jednostki; a raczej norma ta nakazuje «pozostawienie twarzy» - liu mianzi ${ }^{\text {"20 }}$.

Krytyka jest często nieodzownym elementem konfliktu. Szczególnie w sytuacjach kontaktu międzykulturowego wybranie odpowiedniej strategii - z jednej strony przekazania konstruktywnych słów krytyki, a z drugiej niedopuszczenia do utraty twarzy u rozmówcy - jest dla obcokrajowców pracujących z Chińczykami bardzo trudne. Chińczycy traktują krytykę bardzo osobiście, nawet, gdy dotyczy ona jedynie formy wykonywanej przez nich pracy, co potwierdzają słowa Young'a ${ }^{21}$ : „Chińczycy uważają pomysły danej osoby za ściśle związane z jej tożsamością czy poczuciem własnej wartości; atak na jej pomysły jest przez to atakiem na jej tożsamość czy ściślej - na jej twarz". Dlatego właśnie, jeżeli krytyka jest nieunikniona, Chińczycy podejmują działania zmierzające do złagodzenia jej lub przekazania w sposób wysokokontekstowy - w niebezpośrednich słowach ${ }^{22}$. Asertywność, tak ceniona w relacjach między członkami np. kultury amerykańskiej, w Chinach oznacza zbyt duży przejaw indywidualizmu i brak troski o pozytywne relacje z innymi. Można więc zadać pytanie - jakimi słowami Chińczycy odmawiają spełnienia prośby czy komunikują odmowę? Oczywiście nie mówią wprost „nie”, lecz używają takich stwierdzeń, jak: „You xie wenti” - „będą z tym pewne problemy”, „Bu fangbian” - „,nie jest to fortunne” czy „Youxie Kunnan” - „Będa z tym pewne trudności”, a także „Women yanjiu yanjiu” - „Rozważymy to",23.

Treści, które w kulturach indywidualistycznych zostałyby uznane za ,,szczere”, Chińczycy przekazują w postaci yilun - „ploteczek”, a więc nieoficjalnych rozmów w bardzo wąskim gronie osób zaufanych. Na przykład chińscy uczniowie szkół średnich przyznawali, że najchętniej zwierzają się czy „odsłaniają” przed matkami, na drugim miejscu przed najbliższymi przyjaciółmi, ojcami, potem przed znajomymi, gdy chodzi o sprawy związane z kwestiami ogólnymi i relacjami w rodzinie. Tematy związane z seksualnością omawiane są z najbliższymi przyjaciółmi ${ }^{24}$. Ponieważ komunikowanie indywidualnych poglądów i opinii „oficjalnie”, ,na forum” może grozić utratą twarzy osób zaangażowanych, forma yilun - ,plotek” stwarza okazję do narzekania na szefów, rodziców, nauczycieli, czyli wszystkich tych, którzy stoją wyżej w hierarchii społecznej od osoby, która treści te wyraża.

„Ren yao lian, shu yao pi” (,Ludzie potrzebują twarzy, jak drzewo potrzebuje kory") to często używane przez Chińczyków przysłowie, które podkreśla

\footnotetext{
${ }^{20}$ Ibidem, s. 61.
}

${ }^{21}$ L. W. Y o u n g, Cross-talk and culture in Sino-American communication, Cambridge University Press, Cambridge 1994.

${ }^{22}$ M. H. B o n d, K. K. H u a n g, The social psychology..., s. 248.

${ }^{23}$ G. G a o, S. T i n g - T o o m e y, Communicating Effectively..., s. 64-65.

${ }^{24}$ Ibidem, s. 66. 
elementarną potrzebę posiadania „twarzy” w ich kulturze. Mianzi wpływa na to, jak Chińczycy widzą samych siebie, swoje relacje z innymi ludźmi, a także na to, jaki wizerunek prezentują w sytuacjach publicznych. Konieczność „posiadania twarzy" i nie dopuszczenia do jej utraty wiąże się ze sposobem komunikacji, jaki preferują Chińczycy. Jest ona niebezpośrednia; Chińczycy zaledwie implikują lub sugerują to, co chca powiedzieć. W kulturze chińskiej ceniona jest umiejętność rozumienia informacji nie wypowiedzianych wprost, natomiast „prawda” może zakłócić harmonijne relacje. Płynna i bezkonfliktowa komunikacja to szczególnie wyzwanie dla obcokrajowców, którzy pracują z Chińczykami. Niewerbalne sygnały są jednym z kluczy do zrozumienia treści przekazu w kulturze chińskiej, a informację stanowi to, co nie zostało przekazane słownie. Dlatego też osoby pochodzące z kultur, w których ceniona jest asertywność i szczerość wypowiedzi, muszą nie tylko zważać na to, żeby efektem ich pracy był sukces, lecz także, żeby przebiegała ona w możliwie bezkonfliktowy i kompromisowy sposób. 